\title{
Hvad forstår unge svenskere og nordmænd bedst - engelsk eller dansk?
}

\author{
ChARLOTTE GOOSKENS ${ }^{1}$ \\ Groningen Rijksuniversiteit, Holland
}

\begin{abstract}
The Scandinavian languages are so alike that their speakers often communicate, each using their own language, which Haugen (1966) dubbed 'semicommunication'. This kind of communication is, however, sometimes problematic, especially when it involves Danish. For this reason some Scandinavians prefer to communicate in English. This tendency has been claimed to have become stronger during the last decades and some people see this as a threat to the use of the Scandinavian languages in a Scandinavian context. It is, however, unknown how well Scandinavians understand English in comparison to the neighboring languages. In the present investigation it was investigated how well young Swedes and Norwegians understand English in comparison to Danish by means of written and spoken language tests. The results are explained by means of linguistic and extralinguistic factors.
\end{abstract}

\section{INDLEDNING}

Når mennesker fra forskellige lande og med forskellige modersmål møder hinanden, er det som regel sådan, at i hvert fald den ene part er nødt til at anvende et fremmedsprog for at kunne kommunikere med samtalepartneren. Som bekendt befinder skandinaver, dvs. danskere, svenskere og nordmænd, sig imidlertid i den forholdsvis specielle situation, at de kan bruge deres eget sprog når de kommunikerer med en person fra et af nabolandene. Denne form for kommunikation kaldes for "semi-kommunikation" (Haugen 1966). Kommunikationen mellem skandinaver foregår dog ikke altid helt gnidningsløst. Tidligere undersøgelser af interskandinavisk sprogforståelse har vist, at især svenskere har svært ved at forstå dansk. Danskere er lidt bedre til at forstå svensk, mens nordmænd generelt set er bedst til at forstå nabosprogene. Det er 


\section{Charlotte Gooskens}

desuden også det norske sprog, som bliver forstået bedst af både svenskere og danskere (se f.eks. Maurud 1976, Bø 1978 og Börestam Uhlmann 1994).

Som sagt er kommunikationen mellem skandinaver, og især mellem danskere og svenskere, ofte problematisk, og den almene opfattelse er, at nabosprogsforståelsen er blevet dårligere. De sidste årtier siges det stadig oftere, at det ikke længere er en selvfølge, at en samtale mellem skandinaver føres på de skandinaviske sprog, men at engelsk skulle være lettere at forstå end nabosprogene. Ifølge observationerne taler især unge skandinaver ofte engelsk med hinanden i mange sammenhænge. Dette betyder dog ikke nødvendigvis, at nabosprogforståelsen er blevet dårligere. Den øgede brug af engelsk kan også skyldes, at unge mennesker er blevet bedre til engelsk og i stigende grad føler sig som medlemmer af et internationalt, engelsksproget samfund. Titlen på en bog som Nordisk Ministerråd har udgivet, Engelska språket som hot og tillgång $i$ Norden (Höglin 2002), viser hvor ambivalent man er over for brugen af det engelske sprog som lingua franca. På den ene side giver det en storslået mulighed for mennesker at mødes og kommunikere henover sprog-, kultur- og landegrænser. På den anden side udgør brugen af engelsk en reel trussel mod brugen af de nordiske sprog i en nordisk kontekst. Og der er også mennesker, som frygter, at det engelske sprog på længere sigt vil fortrænge de nordiske sprog som nationalsprog. Truslen har ledt til en livlig samfundsdebat inden for de senere år.

Ohlsson (1977) signalerede allerede den øgede brug af engelsk i Skandinavien og efterlyste en undersøgelse af forholdet mellem nabosprogsforståelse i forhold til forståelsen af engelsk. Hans forventning var, at resultaterne af sådan en undersøgelse ville være, at "man då först på allvar skulle inse grannspråksförståelsens betydelse i Skandinavien" (Ohlsson 1977: 25). På den anden side kommer unge mennesker stadig tidligere og i stadigt større omfang $\mathrm{i}$ kontakt med det engelske sprog, og dette kunne give anledning til at forvente, at i alt fald svenskere og danskere har lettere ved at forstå engelsk end hinandens sprog.

Diskussionen om brugen af engelsk som lingua franca i Skandinavien og efterlysningen af videnskabelige belæg for forholdet mellem nabosprogforståelse og forståelsen af engelsk var anledningen til at udføre den undersøgelse, som beskrives i denne artikel. Målet var at undersøge, hvor godt unge nordmænd og 
svenskere forstår engelsk i forhold til dansk ved hjælp af sprogtester ${ }^{2}$. Vi valgte at fokusere på forståelsen af dansk i forhold til engelsk, fordi dansk som sagt betragtes som problembarnet i interskandinavisk sprogforståelse. Dette gælder specielt for svenskere, og vi forventede derfor, at svenskerne måske ville være bedre til at forstå engelsk end dansk. Derimod forventede vi, at nordmændene har lettere ved at forstå dansk end engelsk, eftersom norsk og dansk ligger så tæt på hinanden sprogligt set, og nordmænd i tidligere undersøgelser har vist sig at være gode til at forstå dansk.

Vi undersøgte både lytteforståelse og læseforståelse. Tidligere undersøgelser (se ovenfor) har vist, at skandinaver er bedre til at læse hinandens sprog end til at forstå dem, når de tales. Det er derfor muligt, at nabosprogsforståelsen, i hvert fald når det gælder læseforståelsen af en tekst, har et forspring i forhold til engelsk.

Vi søgte forklaringer på resultaterne ved hjælp af svar på spørgsmål, som skulle give indsigt $\mathrm{i}$ hvor meget kontakt testpersonerne havde med engelsk og dansk samt i deres holdninger til det danske sprog. Desuden regnede vi lingvistiske afstande ud ved hjælp af den såkaldte Levenshtein-metode. Dette gjorde det muligt at se på forholdet mellem sprogforståelse og lingvistiske afstande.

\section{EKSPERIMENTET}

For at teste den engelske og danske sprogforståelse udviklede vi en test, hvor testpersonerne skulle oversætte engelske eller danske ord i en sætning. Ved valget af testmaterialet var der et antal faktorer, som det var vigtigt at tage hensyn til. Eftersom vi ville være i stand til at sammenligne lytteforståelse og læseforståelse, mente vi for det første, at det var vigtigt, at basere testene på de samme tekster, og at det var de samme ord, som testpersonerne skulle oversætte.

Vi mente, at det ville være bedst at undgå at tage en dansk tekst som udgangspunkt og oversætte denne tekst til engelsk eller omvendt. Brugen af en tekst, som oprindeligt er skrevet på dansk, kunne for eksempel have den effekt, at specielle danske ord og udtryk, som er svære at oversætte til engelsk, ville dominere. Resultatet kunne derfor være, at de to teksters sværhedsgrad var forskellig. Vi valgte derfor at tage vores udgangspunkt i en hollandsk tekst og bruge oversættelser af denne tekst til engelsk og dansk som testmateriale. 


\section{Charlotte GoOskens}

Sprogligt set ligger hollandsk mellem dansk og engelsk (Gooskens og Heeringa 2004), og derfor kan man forvente, at oversættelser til de to sprog er jævnbyrdige.

En anden fordel ved at tage udgangspunkt i en hollandsk tekst var, at det gjorde det lettere for os at vælge testord på en neutral og tilfældig måde. Dette er vigtigt, eftersom vi ønskede at vælge testordene uden tanke på, om de ville være lette eller svære for testpersonerne at oversætte, men snarere som et tilfældigt udsnit af de to sprog. Vi valgte at bruge Anne Franks dagbog som udgangspunkt (Frank 1991). Dette er en berettende tekst, som ikke gør krav på hukommelse eller almenviden, hvis man skal forstå indholdet. Desuden er teksten skrevet i en neutral og relativt enkel stil. På basis af den hollandske tekst valgte vi 30 vilkårlige helsætninger. I hver sætning markerede vi alle indholdsord, og derefter valgte vi et af disse ord i hver sætning efter tilfældighedens princip. Først efter at have valgt de 30 testsætninger og 30 testord ledte vi efter de tilsvarende sætninger og ord i den engelske oversættelse (Frank 1954) og den danske oversættelse (Frank 1977). De 30 engelske og de 30 danske sætninger med hver et udvalgt indholdsord udgjorde vores testmateriale. Ved at vælge materialet på denne måde mente vi at have sørget for, at det engelske og det danske testmateriale var jævnbyrdigt, hvad angår sværhedsgrad, og at testmaterialet repræsenterede de to sprog så godt som muligt.

For at undgå at rækkefølgen af de to sprog, engelsk og dansk, skulle have nogen indflydelse på resultaterne lavede vi to versioner af testen. Version 1 bestod af sætning 1 til 15 på engelsk i tilfældig rækkefølge efterfulgt af sætning 16 til 30 på dansk. I version 2 var rækkefølgen af de to sprog omvendt. Samtidig var de 15 sætninger, som var oversat til engelsk i version 1, oversat til dansk i version 2 og omvendt. Version 2 bestod altså af sætning 1 til 15 på dansk efterfulgt af sætning 16 til 30 på engelsk. Halvdelen af testpersonerne deltog i en test med sætningerne fra version 1 og den anden halvdel deltog i en test med sætningerne fra version 2 .

Som nævnt var vi interesserede i at teste både læseforståelsen og lytteforståelsen. Derfor udviklede vi to tester, en læsetest og en lyttetest. Læsetesten bestod af de i alt 30 (15 engelske og 15 danske) sætninger med hver et understreget 
indholdsord. Under hver sætning var der plads til at skrive oversættelsen af det understregede ord. Her gives et eksempel på en dansk sætning fra testen:

Jeg tager kniven i den ene hånd, sådan, og skraber oppefra og nedefter!

I tidligere undersøgelser af interskandinavisk lytteforståelse har man før målt lytteforståelsen ved hjælp af antal korrekt oversatte ord. Som regel skulle testpersonerne lytte til sætninger og derefter udfylde oversættelserne til deres eget sprog af ord, som var udeladt i skrevne versioner af sætningerne (se f.eks. Maurud 1976, Bø 1978, Börestam Uhlmann 1987). Vi valgte at lade testpersonerne lytte til de 30 sætninger uden nogen støtte fra en skriftlig version af sætningerne for så vidt muligt at efterligne en naturlig situation. På testformularen fandtes kun 30 linjer, hvor oversættelsen af testordet skulle udfyldes. For at gøre testpersonerne klart hvilket ord i hver af de 30 sætninger de skulle oversætte, blev testordet gentaget umiddelbart efter sætningen. Derefter blev sætningen og testordet gentaget endnu engang. Dette mente vi var nødvendigt for at kompensere for, at konteksten er så begrænset i en testsituation som denne, hvor prøvepersonerne kun hørte isolerede sætninger. Desuden havde testpersonerne i læseeksperimentet også lejlighed til at læse sætningerne flere gange. På den måde prøvede vi at gøre testsituationerne så identiske som muligt i de to tester.

Teksterne blev indtalt i et lydstudie på Groningen Universitet. Både den danske og den engelske taler var mænd med en standardudtale af sproget (dansk eller britisk engelsk). Efter vores bedømmelse havde de stemmekvaliteter og læsestile, som ikke var så forskellige, at det kunne give anledning til forskel i forståelighed. Vi bearbejdede optagelserne med Cool Edit for at sørge for, at der var lige lange pauser mellem sætningerne og ordene. Før hver ny sætning indsatte vi desuden en tone for at gøre det lettere for testpersonerne at holde rede på, hvor i eksperimentet de befandt sig.

Før selve testen var der et spørgeskema på testpersonernes eget sprog, som havde til formål at få relevante oplysninger om testpersonernes sproglige og personlige baggrund samt erfaringer med og holdninger til nabosprogene og engelsk. Der 


\section{Charlotte GoOskens}

var spørgsmål om alder, køn og modersmål. Derudover blev de følgende spørgsmål stillet om erfaring med dansk og engelsk, kontakt med danskere og englændere, sprogpræferencer, nabosprogtillid samt holdning til interskandinavisk kommunikation:

1) Hvad forstår du bedst, dansk eller engelsk?

2) Hvor ofte ser du engelske tv-programmer uden tekstning?
$\square$ aldrig
$\square$ mindre end 1 gang om måneden
$\square 1$ gang om måneden
$\square 1$ gang om ugen
$\square$ flere gange om ugen

3) Hvor ofte ser du engelske tv-programmer med tekstning?

4) Hvor ofte ser du danske tv-programmer uden tekstning?

5) Hvor ofte ser du danske tv-programmer med tekstning?

6) Hvor ofte læser du engelske tekster (for eksempel bøger, aviser, på internettet)?

7) Hvor ofte læser du danske tekster (for eksempel bøger, aviser, på internettet)?

8) Har du nogensinde talt med en dansker?

a. Hvis du har: på hvilket sprog foregik samtalen så?

b. Hvis du ikke har: hvilket sprog ville du anvende hvis du traf en dansker?

9) Har du nogensinde skrevet et brev eller en e-mail til en dansker?

a. Hvis du har: på hvilket sprog foregik korrespondensen?

b. Hvis du ikke har: hvilket sprog ville du anvende hvis du skrev til en dansker?

10) Hvor vigtigt er det for dig, at du kan tale et nordisk sprog med dine nordiske naboer?
$\square$ meget vigtigt
vigtigt
$\square$ ikke så vigtigt
$\square$ slet ikke vigtigt

Spørgsmål 2, 3, 4, 5, 6 og 7 kunne besvares på en skala fra 'aldrig' til 'flere gange om ugen' på samme måde som illustreret ved spørgsmål 2. Spørgsmål 8 stilledes 
kun til deltagerne i lyttetesten og spørgsmål 9 kun til deltagerne i læsetesten. Spørgsmål 10 kunne besvares på en skala fra 'meget vigtigt' til 'slet ikke vigtigt' . De øvrige spørgsmål (1, 8 og 9) var åbne spørgsmål.

Som testpersoner valgte vi norske og svenske elever fra sidste klasse i ungdomsskolen, som havde norsk henholdsvis svensk som modersmål. Eleverne på dette trin i undervisningen er mellem 14 og 16 år gamle. De svenske elever var gennemsnitligt 15,1 år, og de norske elever var godt et halvt år yngre (14,5 år). Vi gik ud fra, at eleverne i sidste klasse i ungdomsskolen i Norge og Sverige har haft omtrent lige meget engelskundervisning, hvilket ville gøre det muligt at sammenligne elevernes resultater både på den engelske og på den danske del.

Der deltog i alt 320 elever i undersøgelsen, omtrent lige mange drenge (156) og piger (164). I Tabel 1 gives en oversigt over fordelingen af eleverne over de to lande, de to versioner og de to testtyper. Der var 172 norske elever og 148 svenske elever. Der var 163 elever som deltog i testversion 1 og 157 som deltog $\mathrm{i}$ testversion 2. 149 deltog i læsetesten og 171 i lyttetesten.

Det var forskellige elever fra forskellige skoler, som deltog i de to tester. I alt deltog 6 norske og 7 svenske skoler i undersøgelsen. Vi forsøgte at matche skolerne så godt som muligt. Vi valgte skoler som geografisk set lå midt i landet, omtrent lige langt fra Danmark. På den måde sørgede vi for, at grupperne var ligestillede, hvad angår den mængde af kontakt, som de kunne forventes at have haft med danskere og det danske sprog. De norske skoler lå i området sydvest for Trondheim i Møre og Romsdal eller syd for Lillehammer. De svenske skoler lå alle i Dalarne.

For at stimulere eleverne til at deltage udlovede vi en belønning til den elev i klassen, som havde det største antal rigtige besvarelser på testen. 


\begin{tabular}{lccccc}
\hline & \multicolumn{2}{c}{ læsetest } & \multicolumn{2}{c}{ lyttetest } & \\
& Sverige & Norge & Sverige & Norge & total \\
\hline version 1 & 36 & 50 & 42 & 35 & 163 \\
version 2 & 34 & 51 & 36 & 36 & 157 \\
total & 70 & 101 & 78 & 71 & 320 \\
\hline
\end{tabular}

Tabel 1. Fordelingen af antal elever over de to lande (Sverige og Norge), de to versioner (version 1 og version 2) og de to testtyper (læseforståelse og lytteforståelse).

Besvarelserne på sprogtestene blev kodet på følgende måde. En leksikal forkert oversættelse fik 0 point, en morfologisk forkert men leksikal korrekt oversættelse fik 1 point, og en helt korrekt oversættelse fik 2 points. Der blev ikke givet points for en morfologisk korrekt men leksikalt forkert oversættelse ${ }^{3}$. Hver prøveperson kunne altså opnå mellem 0 og 30 points per sprog (15 sætninger x 2 points).

\section{RESULTATER}

Først ser vi på resultaterne af selve testene i afsnit 3.1., og derefter søger vi forklaringer på resultaterne ved at relatere dem til svarene på spørgsmålene i spørgeskemaet og ved at korrelere dem med lingvistiske afstande mellem sprogene (afsnit 3.2.).

\subsection{Resultater af lytte- og læsetestene}

For hver testperson blev procentdelen af korrekte oversættelser regnet ud, både for den engelske del af testen og for den danske del. I Figur 1 præsenteres resultaterne af de to tester for de to lande (Sverige og Norge), de to sprog (engelsk og dansk) og de to testtyper (læsetest og lyttetest). 


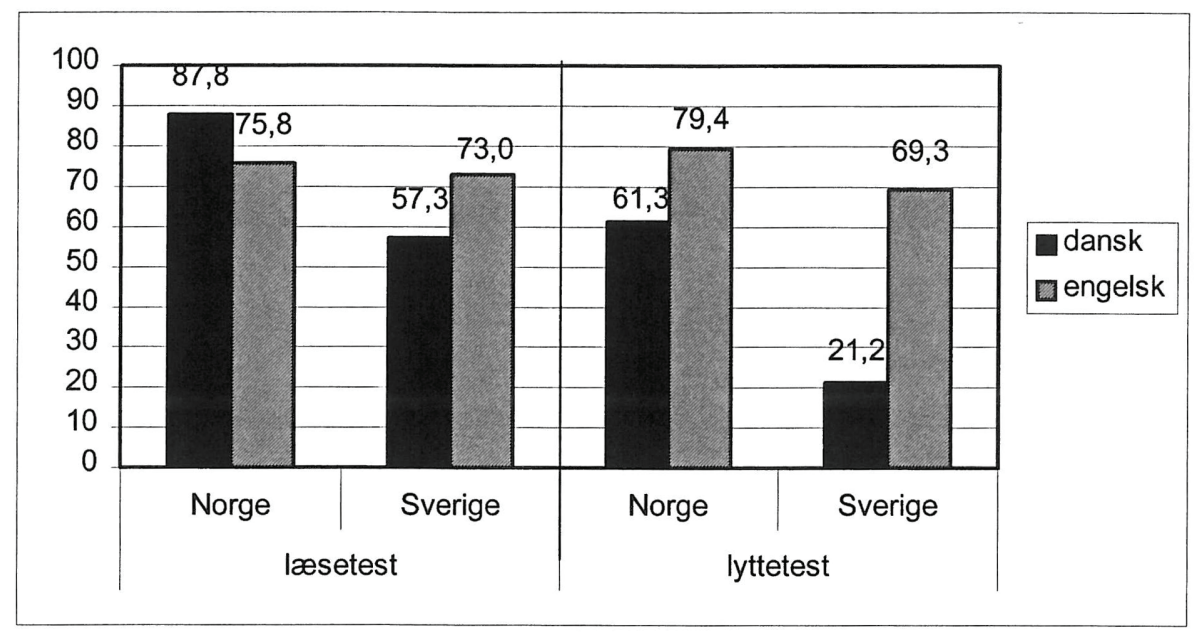

Figur 1. Procentdel danske og engelske ord som er korrekt oversat af testpersoner i Norge og Sverige. Til venstre resultaterne af læsetesten og til højre resultaterne af lyttetesten.

Svenskernes danskforståelse er temmelig dårlig. De har kun oversat 21,2\% af ordene korrekt i lyttetesten og 57,3\% i læsetesten. Hovedformålet med vores undersøgelse var at sammenligne forståelsen af engelsk med forståelsen af dansk, og det viser sig, at det er meget lettere for svenskerne at forstå engelsk, end det er for dem at forstå dansk. Forskellen er dog meget større, når det gælder om at forstå talesprog (en forskel på 48,1\%, $t=23,47, d f=1,75, p=.00$ ) end når det gælder skriftsprog (en forskel på 15,7\%, $t=8,46, d f=1,54, p=.00$ ).

Nordmændene er gode til at forstå dansk. Dette gælder især for skrevet dansk, hvor de oversatte $87,8 \%$ af ordene korrekt. Resultaterne af den danske lyttetest er dårligere (61,3\% korrekte oversættelser). Ligesom svenskerne er nordmændene bedre til at forstå engelsk talesprog end til at forstå talt dansk (en forskel på $18,1 \%, t=7,51, d f=1,70, p=.00)$. Når det gælder skriftsproget viser dansk sig derimod at være lettere for nordmændene at læse end engelsk (en forskel på $12,0 \%, t=-7,63, d f=1,95, p=.00)$.

Hvis vi sammenligner svenskernes resultater med nordmændenes, viser det sig, at nordmændene er bedre end svenskerne over hele linjen. De er især bedre både til at læse og forstå dansk. Forskellen er 30,5\% for skriftsprogsforståelsen ( $t=282,68, d f=1,155, p=.00)$ og 40,1\% for talesprogsforståelse ( $t=205,63, d f=1,147$, 


\section{Charlotte GoOskens}

$p=.00$ ). Det viser sig, at de også er lidt bedre til engelsk. Forskellen på læsetestene er dog meget lille og ikke signifikant $(2,8 \%, t=1,06, d f=1,163, p=.30)$, men når det gælder mundtlig sprogforståelse er der en signifikant forskel $(10,1 \%, t=12,98$, $d f=1,147, p=.00)$. Nordmændene er altså bedre til at forstå talt engelsk end svenskerne.

Både svenskerne og nordmændene er betydeligt bedre til at læse dansk end til at forstå det, når det tales. Dette er hvad man kunne forvente. Det danske sprog har været i udtalemæssigt skred i de sidste 150 år, og udviklingen er gået hurtigere end i de øvrige nordiske sprog (Brink 1988: 30). Det danske skriftsprog har derimod ikke ændret sig i takt med udtalen og ligner derfor både norsk og svensk mere end udtalen.

Som sagt er det ikke før blevet testet, hvor godt skandinaver forstår hinandens sprog i forhold til engelsk. Resultaterne stemmer dog overens med resultaterne af en enquete, hvor deltagerne $\mathrm{i}$ et nordisk møde blev spurgt om på en skala fra 1 (meget godt) til 5 (meget dårligt) selv at bedømme, hvor godt de forstod det, der blev sagt på dansk, norsk, svensk og engelsk. Nordmændene forstod efter eget udsagn bedre dansk (gennemsnitlig score 1,8$)$ end engelsk $(2,1)$, mens det hos svenskerne var omvendt (2,6 versus 2,0), se Börestam (1991).

Det er også muligt at sammenligne resultaterne af den danske del af testen med tidligere undersøgelser. Både Mauruds (1976) og Bøs (1978) resultater viser ligesom vores resultater, at svenskere og nordmænd er noget bedre til at læse dansk end til at forstå det, når det tales. Desuden viser alle resultater, at især svenskere har svært ved at forstå talt dansk, mens nordmændene klarer det rimeligt godt.

\subsection{Forklaringer på resultaterne}

Resultaterne af vores eksperimenter viser altså, at svenskere har lettere ved at læse og forstå engelsk end dansk. Også nordmændene har lettere ved at forstå talt engelsk end talt dansk. Kun når nordmændene skal læse, er dansk lettere for dem end engelsk. Nordmændene har især et forspring i forhold til svenskerne, når det gælder danskforståelsen, men de er også bedre end svenskerne til at forstå talt engelsk. Der er forskellige faktorer, som kan have indflydelse på, hvor

godt testpersoner er i stand til at klare en test i sprogforståelse. Udover 
lingvistiske afstande mellem sprogene er det f.eks. også afgørende, hvilken holdning testpersonerne har til sproget samt deres tidligere erfaringer med sproget. For at få et indtryk af testpersonernes erfaring med dansk og engelsk og deres holdning til brugen af engelsk og skandinaviske sprog $i$ en nordisk kontekst, stillede vi testpersonerne forskellige spørgsmål om disse faktorer (se Afsnit 2). I dette afsnit behandles de vigtigste resultater af spørgeskemaerne og svarene bruges til at søge en forklaring på resultaterne af sprogtestene (se Figur 1). Desuden ser vi på forholdet mellem lingvistiske afstande og testresultaterne.

\subsubsection{Kontakt}

I dette afsnit ser vi på, om de elever, som havde haft mere kontakt med det engelske og det danske sprog, var bedre til at forstå de to sprog end de elever, som ikke havde haft så meget kontakt med sprogene. Vi skelner mellem passiv kontakt via skrevne og talte medier og aktiv kontakt, dvs. personlig kontakt.

\section{Passiv kontakt}

Vi regnede en gennemsnitsscore ud for hvert af spørgsmålene om, hvor meget passiv kontakt eleverne havde med det engelske og det danske sprog. Desuden regnede vi også en total kontaktscore ud. Denne score er det sammenlagte antal point på spørgsmål om, hvor meget engelsk henholdsvis dansk fjernsyn eleverne så, og hvor tit de læste bøger og aviser på de to sprog. Maksimum antal point var 15 for hvert af sprogene, engelsk (spørgsmål 2, 3 og 6) og dansk (spørgsmål 4, 5 og 7). Resultaterne gengives i Tabel 2. Både nordmændene og svenskerne havde mere erfaring med engelsk end med dansk i næsten alle situationer. Nordmændene havde en større totalscore for begge sprog end svenskerne, og de havde også det største antal korrekte besvarelser for begge sprog i sprogtesten (se Figur 1). Vi gik ud fra, at vi ville finde en sammenhæng mellem mængden af kontakt og procentdelen af korrekte oversættelser. I Tabel 2 vises også korrelationskoefficienterne mellem kontaktscorerne og resultaterne af læse- og lyttetestene per land og per sprog. ${ }^{4}$. Mod vores forventninger var der ingen eller i hvert fald meget lav korrelation mellem kontaktscorerne og testresultaterne. Forholdet mellem totale kontaktscorer og testresultat er kun signifikant når det gælder engelsk lytteforståelse i Norge ( $r=.32)$. Der var også en lav korrelation mellem, hvor ofte testpersonerne havde læst dansk og deres danske læseforståelse ( $r=.27$ for svenskerne og $r=.21$ for nordmændene). Vi var altså ikke 


\section{Charlotte GoOskens}

i stand til at påvise en særlig tydelig sammenhæng mellem mængden af passiv kontakt og sprogforståelse.

\begin{tabular}{|c|c|c|c|c|}
\hline & \multicolumn{2}{|c|}{ læsetest } & \multicolumn{2}{|c|}{ lyttetest } \\
\hline & Sverige & Norge & Sverige & Norge \\
\hline \multicolumn{5}{|l|}{ dansk } \\
\hline$\overline{\mathrm{tv}}$ & $\begin{array}{l}1,2 \\
(r=.17 p=.20)\end{array}$ & $\begin{array}{l}1,4 \\
(r=.05 p=.66)\end{array}$ & $\begin{array}{l}1,4 \\
(r=-.01 p=.89)\end{array}$ & $\begin{array}{l}1,9 \\
(r=.21 p=.08)\end{array}$ \\
\hline tv m. tekst & $\begin{array}{l}1,3 \\
(r=.16 p=.38)\end{array}$ & $\begin{array}{l}1,5 \\
(r=.07 p=.50)\end{array}$ & $\begin{array}{l}2,2 \\
(r=-.13 p=.25)\end{array}$ & $\begin{array}{l}2,2 \\
(r=.22 p=.07)\end{array}$ \\
\hline læse & $\begin{array}{l}1,2 \\
\left(r=.27 p=.04^{\star}\right)\end{array}$ & $\begin{array}{l}1,9 \\
\left(r=.21 p=.04^{\star}\right)\end{array}$ & $\begin{array}{l}1,5 \\
(r=-.05 p=.64)\end{array}$ & $\begin{array}{l}1,9 \\
(r=.21 \mathrm{p}=.08)\end{array}$ \\
\hline total & $\begin{array}{l}3,5 \\
(r=.20 p=.14)\end{array}$ & $\begin{array}{l}4,8 \\
(r=.14 p=.19)\end{array}$ & $\begin{array}{l}5,0 \\
(r=-.11 p=.38)\end{array}$ & $\begin{array}{l}6,0 \\
(r=.22 p=.06)\end{array}$ \\
\hline \multicolumn{5}{|l|}{ engelsk } \\
\hline $\mathrm{tv}$ & $\begin{array}{l}3,2 \\
(r=-.12 p=.33)\end{array}$ & $\begin{array}{l}3,4 \\
(r=-.04 p=.73)\end{array}$ & $\begin{array}{l}3,0 \\
(r=-.08 p=.48)\end{array}$ & $\begin{array}{l}3,3 \\
(r=.04 p=.73)\end{array}$ \\
\hline tv m. tekst & $\begin{array}{l}4,8 \\
(r=-.07 p=.55)\end{array}$ & $\begin{array}{l}4,8 \\
(r=.13 p=.20)\end{array}$ & $\begin{array}{l}4,9 \\
(r=.09 p=.42)\end{array}$ & $\begin{array}{l}5,0 \\
(r=.11 p=.35)\end{array}$ \\
\hline læse & $\begin{array}{l}4,1 \\
(r=-.02 p=.88)\end{array}$ & $\begin{array}{l}4,2 \\
(r=.12 p=.26)\end{array}$ & $\begin{array}{l}3,8 \\
(r=.06 p=.60)\end{array}$ & $\begin{array}{l}4,2 \\
(r=.03 p=.82)\end{array}$ \\
\hline total & $\begin{array}{l}11,9 \\
(r=-.11 p=.38)\end{array}$ & $\begin{array}{l}12,4 \\
(r=.07 p=.48)\end{array}$ & $\begin{array}{l}11,7 \\
(r=-.00 p=.98)\end{array}$ & $\begin{array}{l}12,6 \\
\left(r=.32 p=.01^{*}\right)\end{array}$ \\
\hline
\end{tabular}

Tabel 2. Gennemsnitlige kontaktscorer (minimum er 1 og maksimum er 5) og totale kontaktscore (minimum er 3 og maksimum er 15) og pearson korrelationskoefficient (i parentes) mellem kontaktscorer og procentdel korrekte besvarelser på testen pr. testtype, land og sprog. * betyder at korrelationen er signifikant på 0,05-niveauet.

\section{Aktiv kontakt}

I modsætning til engelsk, som læres i skolen, får man i Skandinavien ingen eller kun meget lidt undervisning i de andre skandinaviske sprog. Hvis man vil opnå en bedre forståelse af nabosprogene, er det derfor først og fremmest afgørende at komme i kontakt med sprogene. En sådan kontakt kan være passiv gennem medierne, men vi gik ud fra, at det måske er vigtigere for evnen til at forstå dansk, at man har haft personlig kontakt med en dansker, enten skriftligt eller mundtligt. Derfor spurgte vi, om eleverne havde haft mundtlig eller skriftlig kontakt med en dansker (spørgsmål 8 og 9). Deltagerne i lyttetesten svarede kun på spørgsmål om mundtlig kontakt og deltagerne i læsetesten besvarede kun spørgsmål om skriftlig kontakt. En oversigt over svarene gives i Tabel 3. Der var mange elever som ikke havde svaret på disse spørgsmål, især på spørgsmålet om skriftlig kontakt. Det viste sig, at flere nordmænd $(85,9 \%)$ end svenskere $(52,6 \%)$ 
havde haft mundtlig kontakt med danskere. Der var næsten ingen, hverken nordmænd eller svenskere, som havde haft skriftlig kontakt med danskere $(0,0 \%$ og 3,0\%). Man kunne forvente, at prøvepersoner, som har haft kontakt med en dansker, ville være bedre til at forstå sproget end dem, som ingen kontakt har haft. Procenterne i parentes i Tabel 3 viser resultaterne på lytte- og læsetestene for testpersoner, som havde erfaring med dansk via personlig kontakt, og for dem uden erfaring. Mod vores forventninger viste det sig, at det ikke gjorde nogen forskel for testresultaterne, om eleverne havde erfaring med dansk via personlig kontakt eller ej.

\begin{tabular}{lllll}
\hline & \multicolumn{2}{c}{ skriftlig kontakt (læsetest) } & \multicolumn{2}{c}{ mundtlig kontakt (lyttetest) } \\
& Sverige & Norge & Sverige & Norge \\
\hline kontakt & 0,0 & $3,0(83,3)$ & $52,6(21,9)$ & $85,9(59,7)$ \\
ikke kontakt & $8,6(58,3)$ & $85,1(88,1)$ & $39,7(20,8)$ & $14,1(71,0)$ \\
intet svar & $91,4(57,3)$ & $11,9(86,6)$ & $7,7(17,5)$ & 0,0 \\
\hline
\end{tabular}

Tabel 3. Procentdel elever som havde haft eller ikke havde haft skriftlig kontakt (læsetesten) eller mundtlig kontakt (lyttetesten) med en dansker samt procentdel korrekte besvarelser på den danske test (i parentes) pr. testtype og land.

\subsubsection{Holdning til brug af engelsk og skandinavisk}

Sprogholdninger kan forventes at have indflydelse på sprogforståelse. Hvis en testperson f.eks. har en positiv holdning over for brugen af skandinavisk sprog $\mathrm{i}$ interskandinavisk kommunikation, kan han i højere grad forventes at yde sit bedste i den danske del af testen, end hvis han er negativt indstillet. Vi forsøgte at få et indtryk af elevernes holdning til brugen af engelsk og skandinavisk på flere forskellige måder. Vi ser her på, hvilket sprog de foretrækker at bruge i kommunikationen med danskere, engelsk eller dansk, og på hvilket sprog de regner med at have lettest ved at forstå. Desuden ser vi på, hvor vigtigt testpersonerne synes det er at kunne kommunikere på skandinavisk med deres nordiske naboer.

\section{Sprogvalg}

Det understreges ofte hvor vigtigt der er for den interskandinaviske sprogforståelse, at viljen til at kommunikere på skandinavisk og troen på, at det er muligt, er til stede. Hvis eleverne selv tror på, at det er muligt at kommunikere på skandinavisk, er der sandsynligvis en større chance for, at det lykkes dem at 
kommunikere på deres eget sprog, og at de ikke vælger at gå over til brugen af engelsk. Eleverne blev spurgt om, hvilket sprog de havde brugt eller ville bruge i mundtlig og i skriftlig kommunikation med danskere (spørgsmål 8a og 8b samt 9a og 9b), fordi vi regnede med at svarene på dette spørgsmål ville afspejle denne vilje eller tro. Svarene bliver sammenfattet i Tabel 4. Som man kan se, er det stort set utænkeligt for de norske elever at tale eller skrive til en dansker på engelsk. 91,5\% af eleverne siger, at de havde talt eller ville tale norsk, hvis de mødte en dansker, mens kun 7,0\% ville tale engelsk. Der var flere nordmænd $(18,8 \%)$, som angav, at de ville bruge eller havde brugt engelsk i skriftlig kommunikation, men der var stadigvæk et stort flertal (70,3\%), som ville skrive norsk. De svenske elever er lidt mere tilbøjelige til at anvende engelsk i mundtlig kommunikation med danskere end nordmændene $(21,8 \%)$. Der er dog stadigvæk et stort flertal af de svenske elever $(74,4 \%)$, som foretrækker deres eget sprog frem for engelsk. Når det gælder skriftlig kommunikation er svenskerne mere tilbøjelige til at vælge engelsk $(51,4 \%)$ end deres eget sprog $(31,4 \%)$.

Man kan forvente, at de elever, som foretrækker deres eget sprog frem for engelsk i kommunikationen med en dansker, er bedre til dansk end de elever, som hellere kommunikerer på engelsk. Dette viste sig også at være tilfældet. Gennemsnitligt klarede de elever, som foretrak at kommunikere på deres eget sprog, den danske test bedre end gruppen, som foretrak engelsk (se tallene i parentes i Tabel 4). Forskellen er særlig stor i gruppen af nordmænd, som deltog i lyttetesten $(79,7 \%$ versus $64,0 \%)$. For engelsk er tendensen som ventet omvendt undtagen for svenskere, som deltog i læsetesten (71,8\% versus 73,0\%). Størst forskel er der igen hos nordmænd, som deltog i lyttetesten (72,0\% versus $60,6 \%)$. 


\begin{tabular}{|c|c|c|c|c|c|c|}
\hline & \multicolumn{3}{|c|}{ skriftlig kommunikation } & \multicolumn{3}{|c|}{ mundtlig kommunikation } \\
\hline & engelsk & $\begin{array}{l}\text { eget } \\
\text { sprog }\end{array}$ & intet svar & engelsk & $\begin{array}{l}\text { eget } \\
\text { sprog }\end{array}$ & intet svar \\
\hline $\begin{array}{l}\text { svenskere } \\
\text { engelsk test } \\
\text { dansk test }\end{array}$ & $\begin{array}{c}51,4 \\
(71,8) \\
(55,9)\end{array}$ & $\begin{array}{c}31,4 \\
(73,0) \\
(58,0)\end{array}$ & 11,4 & $\begin{array}{c}21,8 \\
(73,5) \\
(20,1)\end{array}$ & $\begin{array}{c}74,4 \\
(67,3) \\
(21,5)\end{array}$ & 3,8 \\
\hline $\begin{array}{l}\text { nordmænd } \\
\text { engelsk test } \\
\text { dansk test }\end{array}$ & $\begin{array}{c}18,8 \\
(78,9) \\
(87,1)\end{array}$ & $\begin{array}{c}70,3 \\
(76,6) \\
(88,3)\end{array}$ & 10,9 & $\begin{array}{c}7,0 \\
(72,0) \\
(64,0)\end{array}$ & $\begin{array}{c}91,5 \\
(60,6) \\
(79,7)\end{array}$ & 1,4 \\
\hline
\end{tabular}

Tabel 4. Procentdel svenskere og nordmænd som siger, at de har brugt eller ville bruge engelsk eller deres eget sprog i skriftlig eller mundtlig kommunikation med danskere, samt procentdel som ikke svarede på spørgsmålet eller svarede, at de ville bruge begge sprog. Tallene i parentes viser procentdelen af korrekte oversættelser.

Det er for øvrigt interessant at se på, om sprogvalget er anderledes hos testpersoner, som aldrig har talt eller skrevet med en dansker end hos dem, der har erfaring med kommunikation med danskere. I Tabel 5 har vi opdelt resultaterne fra lyttetesten i Tabel 4 i en gruppe, som tidligere havde haft mundtlig kontakt med en dansker og i en gruppe, som ikke tidligere havde haft kontakt. Vi har udeladt resultaterne fra læsetesten i Tabel 5, fordi der var for mange svenskere, der ikke havde svaret på dette spørgsmål. Desuden var der kun 3 nordmænd som havde haft skriftlig kontakt med danskere (se Tabel 3). Som vi så i Tabel 3, var der 39,7\% af svenskerne, som angav aldrig at have talt med en dansker, og det er bemærkelsesværdigt, at andelen af elever i denne gruppe, som sagde, at de ville bruge engelsk, hvis de mødte en dansker, var noget større $(41,4 \%)$ end andelen i gruppen, som tidligere havde haft mundtlig kontakt med en dansker $(7,1 \%)$. Det samme forhold gør sig gældende hos nordmændene (33,3\% versus 3,3\%). Tilsvarende er der flere både nordmænd og svenskere med tidligere danske kontakter, som svarede, at de havde brugt deres eget sprog (henholdsvis 92,9\% og 96,7\%), end der var i den gruppe, som ikke tidligere havde haft kontakt (58,6\% og 66,7\%). Det virker altså som om, at både svenskere og nordmænd har andre forventninger til, hvordan en samtale med en dansker kan forløbe, end den i virkeligheden viser sig at gøre. Mange regner med, at det er nødvendigt at tale engelsk, men i praksis viser det sig at være muligt at kommunikere ved hjælp af deres eget sprog. 


\begin{tabular}{lcccc}
\hline & \multicolumn{2}{c}{ mundtlig kontakt } & \multicolumn{2}{c}{ ikke-mundtlig kontakt } \\
& engelsk & eget sprog & engelsk & eget sprog \\
\hline svenskere & 7,1 & 92,9 & 41,4 & 58,6 \\
nordmænd & 3,3 & 96,7 & 33,3 & 66,7 \\
\hline
\end{tabular}

Tabel 5. Procentdel svenskere og nordmænd med og uden tidligere mundtlig kontakt med danskere, som siger, at de har brugt eller ville bruge engelsk eller deres eget sprog i mundtlig kommunikation med danskere.

\section{Egne forventninger}

Man kan gå ud fra at elever, som havde en positiv forventning til deres egen danskforståelse, også var bedre til at forstå dansk, fordi de havde en større vilje til at prøve at forstå det. Vi spurgte eleverne om, hvilket sprog de bedst kunne forstå, engelsk eller dansk (spørgsmål 1). Det blev ikke nærmere defineret, om der mentes skriftlig eller mundtlig sprogforståelse. I Tabel 6 kan man se, hvor stor andel af de norske og svenske deltagere i læsetesten og i lyttetesten forventede at være bedst til engelsk og til dansk, samt hvor mange af disse elever, der havde de korrekte forventninger. Der var kun en enkelt svensk elev, som svarede, at han var bedre til at forstå dansk end til at forstå engelsk, og det viste sig også, at der kun var en elev (ikke den samme), som var bedre til at forstå talt dansk end talt engelsk. De svenske elever er altså meget realistiske, når det drejer sig om deres egen danskforståelse i forhold til engelsk.

Også blandt de norske elever forventede flertallet, at de ville være bedre til at forstå engelsk end dansk. I modsætning til svenskerne er der dog også en del nordmænd, som regner med at være bedst til dansk (15,8\% i læsetesten og 9,9\% i lyttetesten). Især i læsetesten viste elevernes egen vurdering af forholdet mellem deres evne til at forstå de to sprog at være forkert. Som vi ved fra resultaterne af læsetesten (se Figur 1) var eleverne bedre til at læse dansk end engelsk, men eleverne regnede selv med, at de ville være bedst til engelsk.

Det er altså tydeligt, at hverken de svenske eller de norske elever har særlig høje forventninger til deres egen evne til at forstå dansk. Flertallet $\mathrm{i}$ begge grupper forventede, at de ville forstå engelsk bedre end dansk, og især når det gælder lyttetesten bliver denne forventning befæstet af resultaterne. Eleverne var derimod tilbøjelige til at overvurdere deres skriftlige engelskkundskaber. 
Mod vores forventninger viste der sig ikke at være en sammenhæng mellem positive forventninger til danskforståelsen og resultater på dansktesten. I parenteserne i Tabel 6 gengives de danske testresultater delt op efter elevernes forventninger. Det viser sig faktisk, at de elever, som forventede at være bedst til dansk gennemsnitligt, klarede dansktesten lidt dårligere end de elever, som forventede at være bedst til engelsk. Vi har ikke nogen forklaring på dette uventede resultat. Heller ikke i den engelske test synes der at være nogen tydelig sammenhæng.

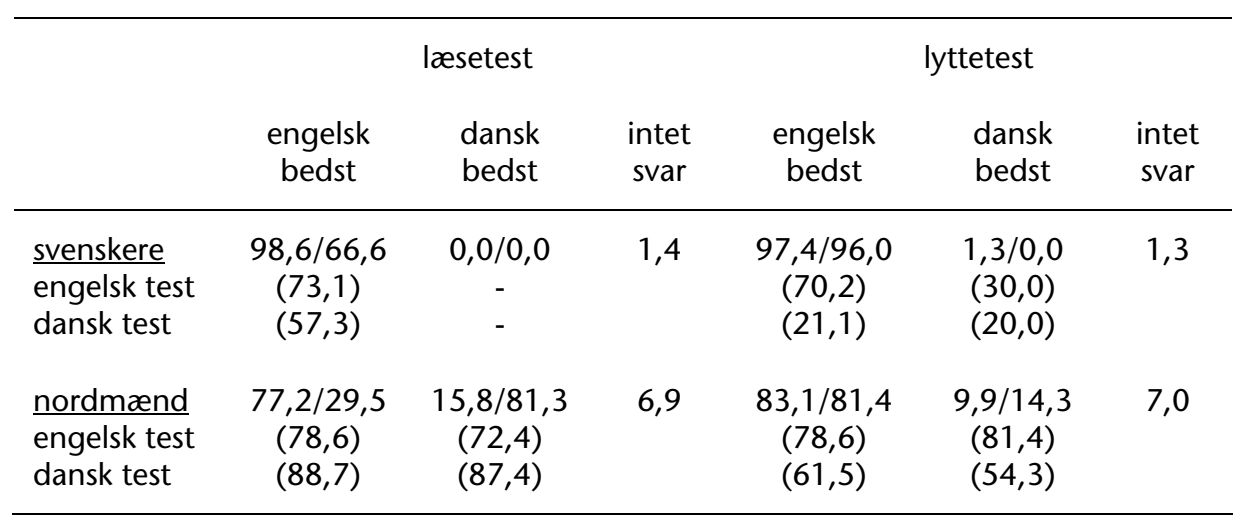

Tabel 6. Procentdel testpersoner som forventede, at de ville kunne forstå engelsk bedre end dansk og procentdel af disse forventninger, som var korrekte (efter skråstregen) pr. testtype og land. Tallene i parentes viser procentdelen af korrekte besvarelser på den danske og den engelske test.

\section{Holdning til interskandinavisk kommunikation}

Man kan også teste, hvor positiv elevernes holdning er over for kommunikation på deres eget sprog med nabofolket, ved at spørge dem om, hvor vigtigt de mener det er at kommunikere med deres nordiske naboer på skandinavisk (spørgsmål 10). De kunne svare på en skala fra 1 (meget vigtigt) til 4 (slet ikke vigtigt). Det viste sig at være vigtigere for nordmændene (gennemsnitligt 2,3 på skalaen) end for svenskerne (gennemsnitligt 2,8). Hvis man går ud fra, at motivation er en vigtig faktor for at kunne forstå et sprog, kunne man forvente en sammenhæng mellem, hvor vigtigt man synes det er at tale skandinavisk og antal korrekte svar på den danske del af testen. Der er dog ingen tydelig effekt. Elever, som synes, at det er vigtigt at tale sammen på et skandinavisk sprog, klarer ikke testen bedre end dem, der ikke synes, at det er vigtigt (se Tabel 7). 


\begin{tabular}{lcccc}
\hline & \multicolumn{2}{c}{ læsetest } & \multicolumn{2}{c}{ lyttetest } \\
& nordmænd & svenskere & nordmænd & svenskere \\
\hline meget vigtigt & $11,9(87,6)$ & $10,0(57,1)$ & $21,1(62,0)$ & $3,8(21,0)$ \\
vigtigt & $48,5(87,3)$ & $20,0(64,2)$ & $32,4(53,5)$ & $23,1(21,8)$ \\
ikke så vigtigt & $33,7(88,3)$ & $51,4(56,0)$ & $36,6(67,3)$ & $62,8(21,5)$ \\
slet ikke vigtigt & $5,0(92,3)$ & $15,7(53,3)$ & $9,9(62,9)$ & $10,3(18,4)$ \\
intet svar & $1,0(80,0)$ & $2,9(50,0)$ & - & - \\
\hline
\end{tabular}

Tabel 7. Procentdel nordmænd og svenskere som mente at det er 'meget vigtigt', 'vigtigt', 'ikke så vigtigt' og 'slet ikke vigtigt' at kommunikere på skandinavisk med nordiske naboer med procentdel korrekte svar på den danske test i parentes, pr. testtype.

\subsubsection{Lingvistiske forklaringer}

I dette afsnit vil vi se på den tredje faktor, som kan forventes at have indflydelse på sprogforståelsen, nemlig lingvistisk afstand. Engelsk læres på skolen som fremmedsprog, og det er selvfølgelig afgørende for, hvor let et sprog er at lære, hvor afvigende det er fra modersmålet, men selve sprogbeherskelsen er afhængig af, hvor meget undervisning man har fået i sproget. Når det drejer sig om at forstå et andet skandinavisk sprog, er det derimod langt mere afgørende, hvor store forskellene er mellem sprogene, eftersom der næsten ikke undervises i nabosprogene i de skandinaviske lande. Sprogforståelsen finder næsten udelukkende sted på basis af lingvistiske ligheder mellem sprogene. Derfor vil der her kun blive set på afstandene mellem dansk på den ene side og de to skandinaviske sprog på den anden side. Der er blevet lavet mange kontrastive beskrivelser af de skandinaviske sprog, men hidtil er der kun blevet foretaget få forsøg på at måle lingvistiske afstande mellem sprogene og vise den direkte sammenhæng mellem lingvistisk afstand og sprogforståelse.

Vi målte afstande mellem de danske 30 ord og ordene på testpersonernes modersmål (svensk eller norsk). Der er flere måder at kvantificere lingvistiske afstande på. Metoden, som vi bruger her, er den såkaldte Levenshtein-metode, som hidtil først og fremmest er blevet brugt til at måle afstande mellem hollandske dialekter (se Heeringa 2004). Fordelen ved denne metode er, at den gør det muligt ved hjælp af computeren at måle afstande mellem forskellige sprogvarianter på en objektiv måde på basis af en kvantitativ analyse. Levenshtein-afstande er de minimale omkostninger ved at ændre en række 
symboler til en anden række. Basisomkostningerne er tilføjelser, fjernelser og erstatninger. Den simpleste version af metoden er den hvor lingvistiske afstande regnes ud på basis af binære forskelle: forskellige symboler bidrager til en lingvistisk afstand, identiske symboler bidrager ikke. Desuden bliver der også taget højde for ordenes længde ved at dividere omkostningerne ved at ændre et ord til et andet med antallet af symbolpar som sammenlignes. Metoden bliver behandlet detaljeret i Heeringa (2004). Her gives et eksempel på hvordan man kan regne Levenshtein-afstanden ud mellem det danske ord 'nød' og det tilsvarende ord på svensk 'njöt':

\begin{tabular}{|lllll|}
\hline \multicolumn{5}{c|}{ dansk nød $\rightarrow$ svensk njöt } \\
\cline { 2 - 5 } symbolpar & 1 & 2 & 3 & 4 \\
\hline dansk & $\mathrm{n}$ & - & $\varnothing$ & $\mathrm{d}$ \\
svensk & $\mathrm{n}$ & $\mathrm{j}$ & ö & $\mathrm{t}$ \\
\hline omkostninger & & 1 & 1 & 1 \\
\hline
\end{tabular}

Omkostningerne $(1+1+1=3)$ deles nu med antallet af sammenlignede symbolpar $(4)^{5}$. Dette giver en afstand på 0,75 eller $75 \%$. I vores undersøgelse havde vi 30 forskellige testord. Når man sammenligner to sprog, får man altså 30 afstande. Afstanden mellem de to sprog er gennemsnittet over de 30 afstande. Når man skal måle afstandene mellem talt sprog, måler man afstandene på basis af fonetiske transskriptioner. Her kan man bruge en mere følsom version af metoden, som tager højde for, at afstanden mellem parret [a,p] bør regnes for større end afstanden mellem parret $[b, p]$. Vi begrænsede os dog til at beregne afstandene på basis af skriftsproget med binære forskelle. Grunden er, at vi kun havde optagelser af de 30 danske ord, men for at måle afstandene til talt svensk og norsk ville vi også have brug for optagelser af de samme ord i den samme kontekst for norsk og svensk.

Gennemsnitsafstanden mellem de 30 ordpar i vores undersøgelse var $44 \%$ mellem dansk og svensk og 10\% mellem dansk og norsk. Der viste sig at være høje korrelationer mellem de lingvistiske afstande og testresultaterne, især når det gælder læsetestene ( $r=0,77$ for svensk og $r=0,71$ for norsk). Disse korrelationer 


\section{Charlotte Gooskens}

er signifikante på 0,01-niveauet. Det er altså muligt til en vis grad at forudsige, hvor godt nordmænd og svenskere kan læse danske ord på basis af ordenes afvigelsesgrad. Det er uvist i hvor stor grad prøvepersonerne gjorde brug af konteksten, når de skulle oversætte det ene ord i hver sætning. Doetjes (2003) testede svenske ord med og uden kontekst blandt danske og norske gymnasieelever. Det viste sig, at eleverne var signifikant bedre til at oversætte ordene, hvis de stod i en kontekst. Det er altså muligt, at korrelationerne mellem lingvistiske afstande og antallet af korrekte oversættelser ville have været højere, hvis testpersonernes opgave havde været at oversætte ordene uden kontekst.

Som nævnt ville det bedste have været bedre at korrelere lyttetestenes resultater med Levenshtein-afstande baseret på fonetiske transskriptioner, men vi mente alligevel, at det ville give et vist indtryk af forholdet mellem lingvistiske afstand og resultaterne af lyttetestene at korrelere dem med Levenshtein-afstandene baseret på skriftsproget. Det viste sig også, at der var rimeligt høje korrelationer i tilfælde af lyttetestene ( $r=0,66$ for svensk og 0,52 for norsk). Også disse korrelationer var signifikante på 0,01-niveauet. Der er altså et tydeligt forhold mellem lingvistiske afstande og dansk sprogforståelse blandt nordmænd og svenskere, både når det gælder læseforståelse og lytteforståelse.

\section{KONKLUSIONER}

Et af Nordisk Råds formål er at styrke brugen af de skandinaviske sprog i en internordisk kontekst. Rådet har bl.a. udgivet en folder med råd til nordboere om, hvad de kan gøre for at opnå god indbyrdes forståelse (Nordiska Rådet $\left.1993^{6}\right)$. Heri anbefales det at undgå brugen af engelsk som nordisk omgangssprog. Som argumenter herfor nævnes, at man kan udtrykke sig friere og mere nuanceret på sit eget sprog, og at de skandinaviske sprog ofte er bedst egnede til at udtrykke sig på, når det drejer sig om nordiske forhold. Desuden er ikke alle lige gode til engelsk, mens det kræver en forholdsvis lille indsats at kunne forstå de andre skandinaviske sprog. Også de nordiske sprogs symbolske værdi som skaber af nordisk identitet understreges. På den anden side er det spørgsmålet om sprogforståelsen, og især den svensk-danske sprogforståelse, er blevet så dårlig, at man ikke længere kan tale om et sprogfællesskab. I så tilfælde er det måske ikke længere realistisk at tro på, at de nye generationer vil blive ved med at kommunicere med hinanden på et skandinavisk sprog. 
Det var ikke formålet med vores undersøgelse at tage stilling for eller imod brugen af engelsk i internordisk kommunikation. Vores mål var at få et indtryk af, hvor godt skandinaver er i stand til at læse og forstå nabosprog (i dette tilfælde dansk) i forhold til engelsk. Vi konstaterer, at nordmænd er bedre til at læse dansk end engelsk men bedre til at forstå talt engelsk end talt dansk. Svenskerne har flere korrekte oversættelser, både når det gælder talt og skrevet engelsk, end når det gælder dansk.

Svarene på spørgeskemaerne peger i store linjer i samme retning som resultaterne af sprogtestene. Nordmændene var bedre til både skriftlig og mundtlig dansk end svenskerne, og det viste sig også, at nordmændene havde mere passiv og aktiv kontakt med dansk. Der er også flere nordmænd end svenskere, som foretrækker at kommunikere med danskere på deres eget sprog, og der er flere nordmænd end svenskere, som regner med at være bedre til dansk end til engelsk. Internordisk kommunikation anses desuden for at være vigtigere blandt nordmændene end blandt svenskerne. Holdningerne og erfaringerne hos nordmændene stemmer altså overens med testresultaterne, men det var dog kun i et par tilfælde muligt at påvise en direkte sammenhæng med testresultaterne. Derimod viser testresultaterne en tydelig sammenhæng med lingvistiske forskelle. De lingvistiske afstandsmålinger i denne undersøgelse var begrænsede. Det ville sandsynligvis bidrage væsentligt til vores forståelse af den interskandinaviske kommunikation, hvis de lingvistiske afstande på forskellige lingvistiske niveauer mellem sprogene blev kortlagt mere præcist.

Vores resultater er generelt set ikke særligt opmuntrende for modstandere af brugen af engelsk i internordisk kommunikation. Det er dog vigtigt at gøre sig klart, at det er svært at simulere virkeligheden i en testsituation. I vores undersøgelse havde testpersonerne mindre støtte fra konteksten, end de ville have $\mathrm{i}$ en naturlig situation, eftersom hvert ord kun blev præsenteret i en sætning og ikke i en større kontekst. Vores undersøgelse tager heller ikke højde for fordelene ved at kunne udtrykke sig på sit eget sprog. Denne fordel er unik i en situation som den skandinaviske, hvor begge samtaleparter kan udtrykke sig på deres eget sprog og derfor bliver mere jævnbyrdige end i de fleste tosproglige situationer, hvor i hvert fald den ene samtalepartner er nødt til at udtrykke sig på et sprog, som ikke er hans eget. 


\section{Charlotte GoOskens}

En anden begrænsning ved vores undersøgelse er, at vi kun har testet det danske sprog i forhold til engelsk. Hvis vi havde testet begge nabosprog i alle tre lande, er det sandsynligt, at det ville have givet et andet billede af engelskkundskaberne i forhold til forståelsen af de skandinaviske sprog. Eftersom dansk er problembarnet i den interskandinaviske sprogforståelse, kan man forvente at svensk og norsk vil vise sig at være lettere at forstå end engelsk, især når det gælder skriftsproget. Det er muligvis kun i det dansk-svenske forhold, at engelsk kan konkurrere med skandinavisk, og man kan måske konkludere, at der er en reel fare for, at kommunikationen mellem svenskere og danskere i fremtiden først og fremmest vil komme til at finde sted på engelsk. Det kræver derfor en indsats, hvis man fortsat skal kunne tale om semikommunikation i en svenskdansk kontekst.

Det ville være interessant at undersøge nærmere, hvor udbredt brugen af engelsk i en skandinavisk kontekst er i praksis. Det er muligt, at man i virkeligheden slet ikke så hurtigt går over til at tale engelsk, som man generelt er tilbøjelig til at tro. Resultaterne viste, at en del af både de norske og de svenske elever er tilbøjelige til at overvurdere, hvor godt de er i stand til at læse engelsk i forhold til dansk. Men på den anden side er der kun få nordmænd, der bruger eller ville bruge engelsk i en samtale med en dansker. Svenskere som aldrig har haft kontakt med danskere går ud fra, at en samtale med en dansker vil komme til at foregå engelsk, mens det viser sig, at flertallet af de svenskere, som har erfaring med at tale med danskere, talte svensk med dem. Disse resultater viser vigtigheden af at sørge for, at unge skandinaver får mulighed for at mødes og opdage, at det i virkeligheden er muligt at snakke sammen på deres eget sprog.

\section{LITTERATUR}

Brink, Lars (1988), "Den danske udtale”, i: Hansen, Erik, Jørn Lund, (red.) (1988), Sproget her og nu, København: Gyldendal, pp. 20-39.

Вø, Inge (1978), Ungdom og naboland, Stavanger: Rogalandsforskning (rapport 4).

Börestam Uhlmann, Ulla (1987), Dansk-svensk språkgemenskap på undantag, Uppsala: Uppsala Universitet.

Börestam Uhlmann, Ulla (1991), Språkmöten och mötesspråk i Norden, Nordisk språksekretariats rapporter 16, Oslo: Nordisk språksekretariat.

Börestam Uhlmann, Ulla (1994), Skandinaver samtaler. Språkliga och interaktionella strategier i samtal mellan danskar, norrmänn och svenskar, Uppsala: Uppsala Universitet. 
Doetjes, Gerard (2003), "De rol van taalafstand en taalvariatie in de communicatie tussen Zweden, Noren en Denen", Toegepaste Taalwetenschap in Artikelen, 63/1 (2003), pp. 131-142.

Frank, Anne (1954), The diary of Anne Frank, oversat efter den hollandske originaludgave af B. M. Mooyaart-Doubleday, London: Pan.

Frank, Anne (1991), Het Achterhuis: dagboekbrieven 14 juni 1942 - 1 augustus 1944, Amsterdam: Bakker.

Frank, Anne (1977), Anne Franks dagbog, 29. oplag, oversat efter den hollandske originaludgave af H. Løvland, København: Grafisk forlag.

Gooskens, Charlotte, Wilbert Heeringa (2004), "The position of Frisian in the Germanic Language Area", i: Gilbers, Dicky, Maartje Schreuder, Nienke van den Berg (red.) (2004), Festschrift for Tjeerd de Graaf 2004, Groningen: Groningen Universite,t pp. 61-87.

Haugen, Einar (1966), "Semicommunication: The language gap in Scandinavia", Social Inquiry, 33, (1966), pp. 66-81.

Heeringa, Wilbert (2004), Measuring dialect pronunciation differences using Levenshtein distances, Groningen: Groningen dissertations in linguistics (Grodil).

Höglin, Renée (2002), Engelska språket som hot och tillgång i Norden, København etc.: Nordiska ministerrådet.

Maurud, Øyvind (1976), Nabospråksforståelse i Skandinavia: en undersøkelse om gjensidig forståelse av tale- og skriftspråk i Danmark, Norge og Sverige, Stockholm: Skandinaviska rådet.

Nordiska Rådet (1993), Att förstå varandra i Norden: språkråd till nordbor i nordiskt samarbete: en handledning, Stockholm: Nordiska Språksekretariatet och Nordiska Språk- och Informationscentret.

Ohlsson, Stig Örjan (1977), "Nabospråksförståelse. Nabospråk eller grannsprog", Mål og Moele, 4/1 (1977), pp.19-25.

\section{NOTER}

1 Tak til MA-studerende ved Skandinavistisk afdeling, Groningen Universitet, for hjælp til dataindsamlingen i 2001 og 2002.

2 Efter at vores undersøgelse var afrundet, blev der udført en stor undersøgelse af internordisk sprogforståelse, INS-projektet, med støtte fra nordisk kulturfond (Delsing og Lundin Åkesson 2005). I denne undersøgelse blev forståelsen af engelsk også testet.

3 Der var selvfølgelig også andre måder at kode oversættelserne på. Vi kunne f.eks. have lagt større vægt på at ordets leksikalske indhold var korrekt gengivet og tilkendt en leksikal korrekt oversættelse flere points. Eftersom vi ikke ved, hvor vigtig den rigtige opfattelse af ords morfologi er i forhold til den leksikale forståelse for sprogforståelsen, valgte vi denne relativt simple måde at kode besvarelserne på.

4 Vi brugte normerede gennemsnit af testresultaterne for at undgå, at forskelle i sværhedsgraden i de to versioner skulle have indflydelse på korrelationerne. Vi normerede testresultaterne ved pr. land og pr. testsprog at regne forskellen ud mellem gennemsnittet over de to versioner. Halvdelen af dette gennemsnit blev trukket fra resultaterne af versionen med det højeste gennemsnit og lagt til resultaterne af versionen med det højeste gennemsnit. På den måde blev gennemsnittet over de to 


\section{Charlotte Gooskens}

versioner ens og dette gør det muligt at analysere enqueteresultaterne over begge versioner på en gang.

5 Som man kan se, har vi valgt at regne de to symboler " $"$ " og "ö" for forskellige. Det er dog usikkert, hvor forstyrrende de to skriftbilleder virker for en svensker.

6 Se også http://www.nordisk-sprakrad.no/folder_att_forstaa/folder_index.htm 